УДК 616.12-008-088.6

DOI 10.11603/1811-2471.2018.v0.i4.9599

\title{
ЕКОНОМІЧНА ЕФЕКТИВНІСТЬ ТА ОРГАНІЗАЦІЙНІ АСПЕКТИ РЕАЛІЗАЦІЇ ПРОГРАМ КАРДІОРЕАБІЛІТАЦІї ЗГІДНО З МІЖНАРОДНИМ ДОСВІДОМ, ПЕРСПЕКТИВИ РОЗВИТКУ В УКРАЇНІ
}

\author{
๑П. Ф. Колісник, О. В. Долинна, С. П. Колісник, І. В. Баранова \\ Вінницький національний медичний університет імені М. І. Пирогова
}

РЕзюмЕ. Серцево-судинні захворювання (ССЗ) продовжують займати перше місце серед причин смертності працездатного населення, а їх поширеність вища в країнах з низьким та середнім рівнями доходу. В зв'язку з обмеженими фінансовими ресурсами цих країн виникає необхідність раціонального розподілу коштів, виділених на охорону здоров'я. Особливого значення в цих умовах набувають превентивна кардіологія та кардіореабілітація (КР).

Мета - провести огляд наукової літератури, присвяченої економічній ефективності та організаційним аспектам реалізації програм КР у країнах з різним рівнем доходів; запропонувати модель КР для України.

Матеріал і методи. Проведено огляд літератури з обраної теми в наукометричній базі даних MEDLINE та на офіційних електронних ресурсах міжнародних об'єднань кардіологів, лікарів фізичної та реабілітаційної медицини. Пошук проведено за ключовими словами: cardiac rehabilitation, cardiorehabilitation, cardiovascular rehabilitation, low/middle income country, core components, models, benefit, effectiveness, economic effectiveness.

Результати і висновки. У статті проаналізовано ефективність та описано особливості організації КР у країнах з різним рівнем доходів. На основі огляду літератури зроблені висновки щодо можливих шляхів розвитку та запропонована модель організації КР в Україні. Використання альтернативних моделей КР може підвищити ії доступність для більшості населення України, а, отже, покращити якість життя та знизити смертність від ССЗ.

Ключов СловА: кардіореабілітація; ефективність; моделі; країни з низьким і середнім рівнями доходу.

Вступ. Серцево-судинні захворювання (ССЗ) продовжують займати перше місце серед причин смертності працездатного населення, а їх поширеність вища в країнах з низьким та середнім рівнями доходу. В зв'язку з обмеженими фінансовими ресурсами цих країн виникає необхідність раціонального розподілу коштів, виділених на охорону здоров'я. Особливого значення в таких умовах набувають превентивна кардіологія та кардіореабілітація (KP), метою яких є запобігання розвитку CC3, попередження ускладнень та підвищення якості життя пацієнтів [1].

Клінічна та економічна ефективність КР доведена в численних дослідженнях [2-8]. Визначені показання, структура, джерела та обсяг фінансування реабілітаційних програм, які мають відмінності в різних країнах $[2,9]$.

Мета - провести огляд наукової літератури, присвяченої економічній ефективності та організаційним аспектам реалізації програм КР у країнах з різним рівнем доходів; запропонувати модель КР для України.

Матеріал і методи. Проведено огляд літератури з обраної теми в наукометричній базі даних MEDLINE та офіційних електронних ресурсах міжнародних об'єднань кардіологів. Пошук проведено за ключовими словами: сагdiac rehabilitation, cardiorehabilitation, low/middle income country, core components, models, benefit, effectiveness, economic effectiveness.
Результати й обговорення. За визначенням експертів Європейської асоціації превентивної кардіології, кардіореабілітація - це комплекс заходів вторинної профілактики, спрямованих на зниження патфізіологічних, психологічних і соціальних ефектів ССЗ, контроль симптомів та зниження ризику виникнення ускладнень [10].

Позитивний вплив програм кардіореабілітації (ПКР) обумовлений зменшенням смертності та витрат на медичне обслуговування завдяки прискоренню відновлення, досягненню кращих клінічних та поведінкових результатів, зниженню ризику повторних серцево-судинних подій та госпіталізацій, підвищенню якості життя, прихильності до лікування та рекомендацій з модифікації способу життя [2] (табл. 1).

Економічний ефект КР обумовлений:

- зниженням кількості повторних госпіталізацій та летальних випадків унаслідок серцево-судинних подій протягом першого року (на $56 \%$ та 30 \%, відповідно);

- зменшенням використання медичних ресурсів;

- підвищенням якості життя [12].

Згідно з міжнародними рекомендаціями, ПКР мають бути доступними та рекомендуватись, за відсутності протипоказань, усім пацієнтам із ССЗ. Американська асоціація серця та Американська колегія кардіологів визнали КР та вторинну профілактику невід'ємною частиною лікування пацієн- 
Огляди літератури, оригінальні дослідження, погляд на проблему, ювілеї

тів з захворюваннями коронарних артерій та хронічною серцевою недостатністю (IA) $[13,14]$.

Загальноприйнятими показаннями до КР $\epsilon$ протезування клапанів серця, імплантація кардіовертера-дефібрилятора або водія ритму, трансплантація серця, резекція аневризми аорти, іше- мічна хвороба серця (стабільна стенокардія, інфаркт міокарда, реваскуляризація), хронічна серцева недостатність, порушення ритму серця, кардіоміопатія, вроджені вади серця, інші СС3 (захворювання периферійних артерій, інсульт) та високий серцево-судинний ризик [15].

Таблиця 1. Рівень доказовості впливу програм кардіореабілітації на модифікацію факторів ризику серцево-судинних захворювань [11]

\begin{tabular}{|l|c|}
\hline \multicolumn{1}{|c|}{ Наслідки } & Рівень доказовості \\
\hline Відмова від куріння & $\mathrm{B}$ \\
\hline Покращення ліпідного профілю & $\mathrm{A}$ \\
\hline Зниження артеріального тиску & $\mathrm{B}$ \\
\hline Покращення контролю глюкози крові & $\mathrm{B}$ \\
\hline Зниження ваги & $\mathrm{B}$ \\
\hline Підвищення фізичної активності & $\mathrm{B}$ \\
\hline Збільшення фізичної працездатності & $\mathrm{A}$ \\
\hline Поліпшення психосоціального благополуччя & $\mathrm{A}$ \\
\hline Покращення соціального функціонування & $\mathrm{B}$ \\
\hline
\end{tabular}

Цілі КР умовно поділяють на загальні та конкретні.

Загальні цілі KP:

- досягнення максимально можливого фізичного, психологічного та соціального функціонування пацієнтів;

- сприяння змінам поведінки, які можуть мінімізувати ризик виникнення ускладнень ССЗ.

До конкретних цілей КР належать:

- скорочення періоду стаціонарного лікування після гострих серцево-судинних подій;

- розробка стратегій досягнення взаємоузгоджених цілей довготривалої профілактики;

- формування і підтримка навичок довготривалої зміни поведінки та самоконтролю;

- сприяння належному використанню послуг системи охорони здоров'я та суспільних благ у відповідності до призначеного лікування і консультативної допомоги [14].

Основні складові ПКР визначені та узгоджені асоціаціями кардіореабілітації країн з високим рівнем доходів (американська, австралійська, канадська, британська) і професійними міжнародними організаціями, до складу яких входять асоціації з країн, які мають низький чи середній рівень доходу (International Council of Cardiovascular Prevention and Rehabilitation, European Association of Preventive Cardiology, European Society of Physical and Rehabilitation Medicine) [16-18]. Таким чином, незалежно від країни, ПКР складаються 3 обов'язкових компонентів:

- клінічна оцінка стану пацієнта та результатів реабілітації;

- індивідуальний план лікування;

- фізичні тренування, призначені лікарем;

- психосоціальні втручання;

- модифікація факторів ризику ССЗ шляхом навчання пацієнта та поведінкових втручань (консультування з питань здорового харчування, фізичної активності та тренувань, відмови від куріння, контролю нормальної маси тіла, артеріального тиску та рівня ліпідів крові, цукрового діабету) (рис. 1) [16-19].

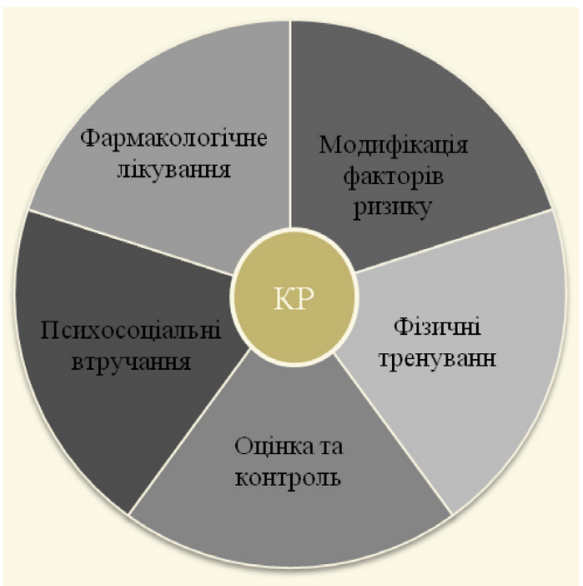

Рис. 1. Основні складові первинної кардіореабілітації $[11,19]$. 
Огляди літератури, оригінальні дослідження, погляд на проблему, ювілеї

Вимоги до основних компонентів ПКР, необхідних людських та технічних ресурсів, організаційних особливостей описані в регламентуючих документах міжнародних професійних об'єднань кардіологів і фахівців з фізичної та реабілітаційної медицини. Існують відмінності, які пов'язані з рівнем та джерелами фінансування КР у різних країнах [16-18].

Реалізація заходів, передбачених програмою кардіореабілітації, відбувається за участі мультидисциплінарної команди спеціалістів, до складу якої можуть бути залучені кардіологи, лікарі фізичної та реабілітаційної медицини, фізіотерапевти, лікарі функціональної діагностики, ендокринологи, неврологи, дієтологи, клінічні психологи, фізичні терапевти (спортивні фізіологи, терапевти з вправ), ерготерапевти, соціальні працівники, середній медичний персонал, а також члени родини. Залежно від кадрового та технічного потенціалу закладу, на базі якого реалізуються вищеперераховані заходи, склад команди та особливості їі організації можуть відрізнятись, але збереження усіх складових ПКР $\epsilon$ обов'язковою умовою. Зокрема, фізичні тренування (ФТ) без інших компонентів не можуть вважатись КР. Обов'язковою умовою організації ПКР є комплексний підхід та наступність дій, що допомагає досягти довготривалого результату $[14,20]$.

ПКР складається з трьох окремих фаз (стаціонарної, амбулаторної, реабілітації на базі громади або вдома). Перша фаза триває до виписки зі стаціонару та передбачає ранню мобілізацію, контроль факторів ризику, навчання та консультування пацієнта, складання індивідуального плану подальших дій, спрямованих на досягнення та підтримку довготривалих результатів. Фаза 2 передбачає амбулаторні програми спостереження та консультування. Третя фаза триває все життя, іï метою $\epsilon$ контроль факторів ризику, сприяння прихильності пацієнта до ведення здорового способу життя та підтримка достатнього рівня фізичної активності. Альтернативними моделями КР можуть бути домашні програми та телереабілітація [21].

Залежно від захворювання, клінічного стану та доступних ресурсів реабілітація осіб з ССЗ складається з усіх трьох фаз або лише з окремих із них. Наприклад, ПКР хворого після перенесеного інфаркту міокарда буде складатись з трьох фаз, тоді як КР пацієнта з компенсованою хронічною серцевою недостатністю або хворого з високим серцево-судинним ризиком може відбуватись лише на амбулаторному етапі та/або вдома. Найпоширеніша модель КР - амбулаторна, тривалість якої зазвичай становить 2-4 місяці [18].

Традиційні групові заняття на базі медичного закладу можуть бути бар'єром для участі мало- мобільних груп населення, пацієнтів молодого віку, які працюють, жінок, осіб, які живуть віддалено, а також хворих з культурними та мовними обмеженнями. Використання сучасних моделей $\mathrm{KP}$, у яких важливе місце займає телереабілітація (професійні електронні ресурси, телефонні додатки, відеоконсультації), дозволяє адаптувати програму до індивідуальних потреб особи [16]. Виявлення бар'єрів для участі в ПКР та вивчення можливостей їх подолання - важлива складова політики в сфері охорони здоров'я держав з розвиненою системою КР і низькою смертністю від ССЗ. 3 досвіду Сполучених Штатів Америки (США), такими бар'єрами можуть бути:

- недостатній рівень направлень на ПКР і низька поінформованість лікарів та пацієнтів стосовно переваг КР;

- відсутність фінансування;

- недостатня прихильність пацієнтів до ПКР;

- робота та домашні обставини;

- відсутність ПКР у сільській місцевості;

- велика відстань до медичного закладу;

- погане транспортне сполучення; вості.

- гендерні, культурні, вікові, расові особли-

3 метою зменшення впливу вищеперерахованих обмежень у США започаткована ініціатива «Million Hearts», в рамках якої створено маршрутну карту пацієнта. Результатом стало підвищення кількості направлень лікарями та прихильності пацієнтів до ПКР. За підрахунками фахівців, така ініціатива зберігає 25000 життів та запобігає 180000 госпіталізацій в США щороку [22].

У статті Маліновської І. Е. та співавторів описані специфічні для України бар'єри участі пацієнтів у ПКР, особливо в фізичних тренуваннях: обмежені фінансові та технічні ресурси, звужений спектр показань до КР, стентування лише інфаркт-обумовлюючої судини при багатосудинному враженні коронарного русла, недостатня кількість та віддаленість медичних закладів, на базі яких реалізуються заходи ПКР [23].

S. A. Lear та A. Ignaszewski запропонували сxему сучасної моделі КР, яка базується на оцінці серцево-судинного ризику та соціально-економічних можливостей пацієнта. Важливе місце в цій моделі належить телемедицині (рис. 2).

Активне використання можливостей телемедицини з метою організації ПКР допомагає подолати бар'єри участі та підвищити прихильність до них пацієнтів [11].

Не зважаючи на доведену ефективність та включення КР до міжнародних стандартів надання медичної допомоги пацієнтам з ССЗ, навіть у розвинених країнах Європи лише 30 \% пацієнтів, з числа тих які мають показання, залучені до ПКР. 
Огляди літератури, оригінальні дослідження, погляд на проблему, ювілеї

\section{Популяція пацієнтів з СС3}

Третинний рівень надання медичної допомоги або сімейний лікар Направлення пацієнтів на ПКР

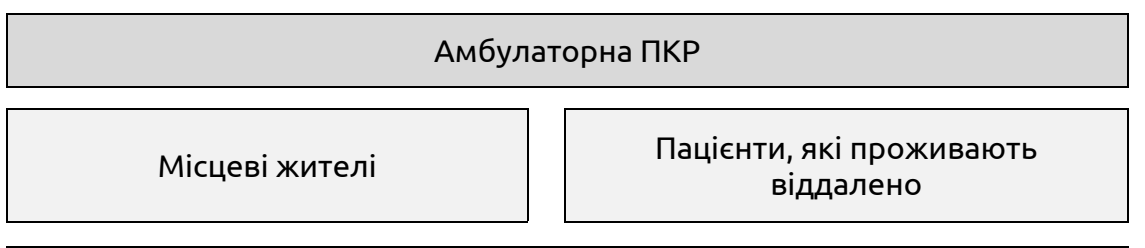

Стратифікація ризику серцево-судинних подій

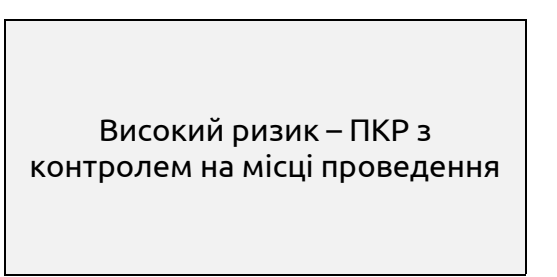

Високий ризик-фізичні тренування з ЕКГ-моніторингом за допомогою телефону та відеоконсультування через мережу Інтернет

Середній ризик-громадський центр/домашні фізичні тренування з консультуванням на місці проведення

Середній ризик-громадський центр/домашні фізичні тренування з відео-консультуванням через Інтернет мережу

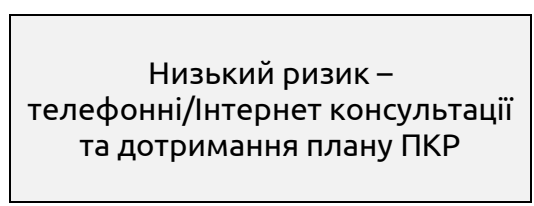

Низький ризик -

телефонні/Інтернет консультації та дотримання плану ПКР

Рис. 2. Схема сучасної моделі первинної кардіореабілітації за S. A Lear та A. Ignaszewski.

Прихильність до ПКР збільшується до 71 \%, якщо лікар надає відповідні рекомендації ще до завершення стаціонарного лікування. Згідно з даними American Heart Fundation, економічний ефект зростання участі в ПКР з $30 \%$ до 50 \% становить 47 мільйонів доларів, залучення 65 \% пацієнтів приводить до економії 86 мільйонів доларів $[24,25]$.

Результати економічного аналізу, проведеного в інших країнах, неможливо екстраполювати на українську популяцію, проте отримані дані доводять економічну ефективність КР та $є$ стимулом до проведення подібних досліджень в Україні. Відмінності у фінансуванні, структурі захворюваності, соціально-культурні, демографічні та генетичні особливості населення в різних країнах впливають на економічну ефективність ПКР. На відміну від країн з високим рівнем доходу, держави з обмеженими фінансовими ресурсами виділяють кошти лише на пріоритетні напрямки сфери охорони здоров'я. Зокрема, поряд із зростаючим тягарем хронічних неінфекційних захворювань ці держави потерпають від інфекційних хвороб, порушень харчування, неонатальної та материнської смертності, що в умовах фінансових обмежень призводить до необхідності зваженого вибору втручань з оптимальним співвідношенням «ціна - користь» [26].

Більшість досліджень, присвячених оцінці економічного ефекту КР, проведені в країнах з високим рівнем доходу. Заходи ПКР, які в них функціонують, складно впровадити в умовах ресурсного обмеження, тому розвиток системи реабілітації у країнах з низьким та середнім рівнями доходу має бути орієнтований на наявний кадровий та матеріально-технічний потенціал, а також розвиток програм реабілітації на базі громади [27].

У результаті проведеного огляду літератури, присвяченого оцінці економічної ефективності ПКР у країнах з обмеженими ресурсами, автори приходять до висновків про ефективність всіх основних компонентів КР та необхідність адаптації іï моделі до можливостей країни. Варіантами вирішення проблем фінансування, на думку експертів, може бути залучення до ПКР суміжних 
Огляди літератури, оригінальні дослідження, погляд на проблему, ювілеї

спеціалістів (медичні сестри, фізичні терапевти, волонтери) і розробка домашніх програм реабілітації та реабілітації на базі громади $[11,16,18,27]$.

У країнах з низьким та середнім рівнями доходу наявний дефіцит спеціалістів, компетентних у галузі реабілітації хворих з ССЗ. Експерти робочої групи Європейської асоціації фізичної та реабілітаційної медицини закликають провідні наукові установи, які надають сучасну кардіологічну допомогу в цих країнах, призначити клінічних педагогів, відповідальних за підготовку фахівців у галузі КР для інших медичних закладів [16].

У 2016 році за підтримки International Council of Cardiovascular Prevention and Rehabilitation nро- ведено міжнародне опитування, метою якого було вивчення особливостей відшкодування витрат на КР у різних країнах. В результаті отримано 31 відповідь 325 країн, більшість з них надійшла з країн які мають високий (КВД) та високий середній рівень доходу (КВСД) (59 \% - КВД, 32,4 \% - КВСД, 9,9 \% - країни з низьким середнім рівнем доходу). Серед джерел фінансування КР 61 \% респондентів вказали на державні, 55 \% - власні кошти пацієнта, $52 \%$ - кошти страхових компаній, $39 \%$ - участь у фінансуванні розподілялась між пацієнтом та іншими джерелами, 23 \% - інші ресурси (КР лише в державних лікарнях, за рахунок фондів, покривається роботодавцем) (рис. 3) [28].

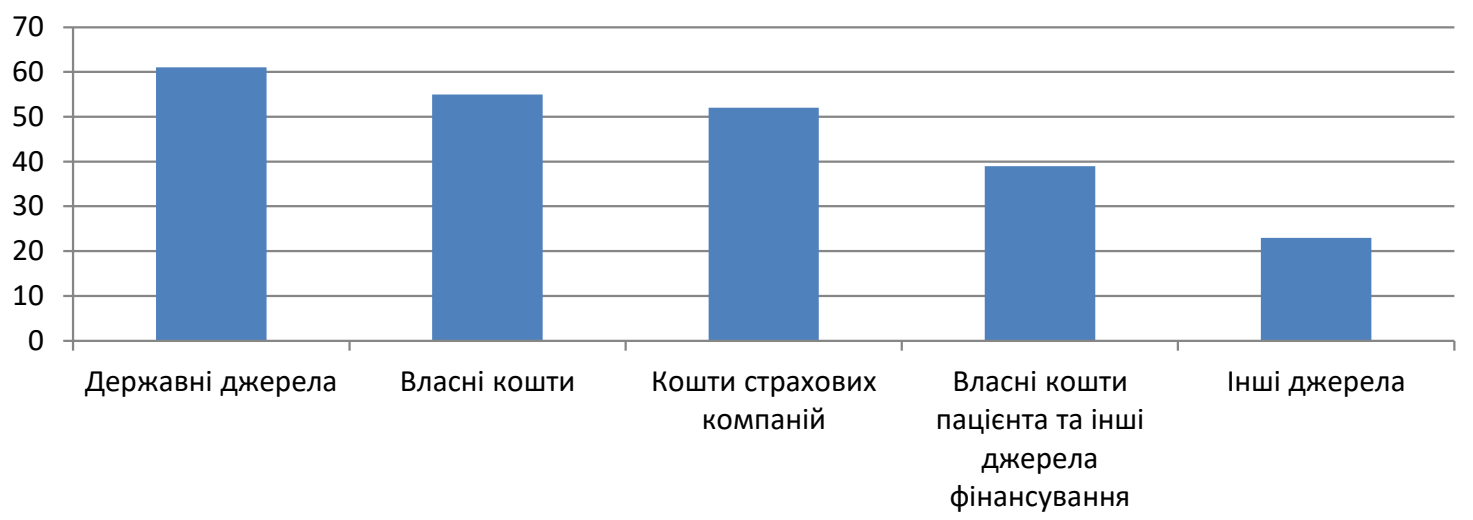

Рис. 3. Структура джерел фінансування ПКР згідно з міжнародним опитуванням International Council of Cardiovascular Prevention and Rehabilitation 2016 року.

У країнах із державним фінансуванням КР тривалість програм складала близько 32 сесій, які на 91,5\% фінансувались державою. Згідно з даними опитування, в більшості цих країн показаннями до КР були: інфаркт міокарда, реваскуляризація, хронічна серцева недостатність, операція на клапанах серця, трансплантації серця, стабільна стенокардія напруги, імплантація водіїв ритму або кардіовертерів-дефібриляторів. ПКР складалась $з$ наступних компонентів: контрольовані фізичні тренування, консультування дієтолога, відмова від куріння, психологічна підтримка, навчання пацієнта, контроль маси тіла, артеріального тиску, ліпідів крові, цукрового діабету, ерготерапія. До складу реабілітаційної команди залучались кардіолог, медична сестра, фізичний терапевт. Показання, складові ПКР та фахівці, залучені до процесу реабілітації, були регламентовані нормативними документами. Подібна ситуація спостерігалась також при фінансуванні ПКР страховими компаніями, проте кількість сесій була меншою (22 сесії), програми фінансувались лише на 48,3\%, частіше це були лише контрольовані фізичні тренування. У США Medicare відшкодовує вартість 36 сесій КР протягом 36 тижнів, з можливістю призначення додаткових 36 сесій. Обов'язковою умовою $\epsilon$ наявність основних складових КР у структурі ПКР [28].

Організація КР має свої особливості в різних країнах. Система охорони здоров'я України перебуває в стані реформування, тому, користуючись досвідом інших країн, має можливість обрати модель $\mathrm{KP}$, яка найкраще відповідає потребам та можливостям держави. Під час огляду літератури знайдено рекомендації з реалізації ПКР в умовах обмежених ресурсів. Автори роблять висновок про економічну ефективність усіх основних компонентів ПКР у країнах з низьким та середнім рівнями доходу і пропонують використовувати альтернативні моделі КР (домашні програми, реабілітація на базі громади, на рівні первинної ланки надання медико-санітарної допомоги) з метою зниження вартості ПКР [19].

В Україні на сьогодні фінансування реабілітаційних послуг для працюючого населення, у разі настання страхового випадку, здійснюється за рахунок коштів Фонду соціального страхування України (ФССУ) на базі санаторно-курортних закладів або за рахунок коштів пацієнта. Згідно з інформацією, розміщеною на офіційному сайті ФССУ, кожен працевлаштований українець має право на відновлення здоров'я після перенесе- 
Огляди літератури, оригінальні дослідження, погляд на проблему, ювілеї

них захворювань або травм у санаторно-курортних закладах (СКЗ) за кошти ФССУ, який покриває 100 \% витрат на медичну реабілітацію. До напрямків реабілітації які фінансуються ФССУ належать кардіопульмонарна реабілітація, нейрореабілітація, м'язово-скелетна реабілітація, медико-психологічна реабілітація учасників АТО, реабілітація після оперативних втручань на органах зору, реабілітація при порушенні перебігу вагітності, інша реабілітація (після оперативних втручань на органах травлення, сечостатевої системи, жіночих статевих органах) $[29,30]$.

Протягом 2018 року за рахунок коштів ФССУ на відновне лікування у реабілітаційних відділеннях санаторно-курортних закладів було направлено понад 15 тисяч застрахованих осіб, частка кардіологічних пацієнтів склала 20,8 \% (гострий інфаркт міокарда, хірургічні втручання на серці) [30].

Перелік СК3, які мають право на відшкодування витрат на реабілітаційні послуги, надані застрахованим особам, затверджено наказом виконавчої дирекції ФССУ від 30.11.2017 № 274-ос. Розділ «Кардіопульмонарна реабілітація» містить 47 рекомендованих СКЗ. Показаннями до направлення в ці заклади $є$ підгострий період інфаркту міокарда (після оперативних втручань на судинах серця або без них), стан після пролікованої нестабільної стенокардії (після оперативних втручань на судинах серця або без них), підгострий період після операцій на серці, підгострий період захворювань легень, підгострий період після операцій на легенях, у тому числі з приводу гнійних процесів нетуберкульозного характеру, цукровий діабет [31].

Питання направлення на реабілітацію в СК3 вирішує лікарсько-консультативна комісія. У разі настання страхового випадку, при якому $є$ показання до направлення на реабілітацію в СК3, медичний заклад повідомляє про нього ФССУ. 3 2018 року механізм замовлення та розподілу путівок на відновлювальне лікування замінило адресне забезпечення медичною реабілітацією, яке передбачає укладення тристороннього договору між ФССУ, СКЗ та пацієнтом. Це дає змогу пацієнту самостійно обирати СК3, на базі якого буде проводитись реабілітація. Такий підхід сприяв переорієнтації СКЗ на реальні потреби в реабілітаційних послугах та створенню умов, в яких СКЗ зацікавлені покращувати якість надання реабілітаційних послуг та підвищувати конкурентоспроможність [31, 32].

За останні роки в Україні проведено ряд заходів, спрямованих на підвищення якості надання медичної допомоги хворим з ССЗ (проект «Поліпшення охорони здоров'я на службі у людей», ініціатива «Рятуємо серця України»): створення но- вих та оснащення існуючих реперфузійних центрів, придбання і безкоштовне встановлення кардіовертерів-дефібриляторів, штучних клапанів, закупівля стентів, заходи щодо налагодження ефективної роботи швидкої медичної допомоги, реперфузійних центрів та кардіологічних відділень [33]. Проте, незважаючи на наявність рекомендацій стосовно КР у державних уніфікованих клінічних протоколах з кардіології, вона залишається недоступною для більшості населення. Окремі компоненти КР наявні на стаціонарному та амбулаторному етапах лікування, але модель, яка може ефективно функціонувати на всій території України, не розроблена. Недостатньо використовуються можливості СКЗ.

Підсумовуючи дані огляду літератури можна зробити висновок про клінічну та економічну ефективність КР. Враховуючи досвід інших країн, створення універсальної моделі КР, яка зробить її доступною для більшості населення України, приведе до суттєвого зниження ризику розвитку ускладнень та смертності від ССЗ.

Висновки. Для створення моделі КР, яка 6 ефективно функціонувала на всій території України, необхідно:

1. В інтервенційних центрах та кардіохірургічних відділеннях запровадити стаціонарні ПКР: протокол ранньої мобілізації, освіта пацієнта, складання плану подальшої реабілітації, створення маршруту пацієнта для скерування на наступний етап реабілітації.

2. На первинному рівні надання медичної допомоги доцільно запровадити амбулаторні ПКР: освіта пацієнта, консультування щодо контролю факторів ризику, призначення фізичних вправ, функціонування програми контрольованих фізичних тренувань на базі медичного закладу.

3. 3 метою підготовки спеціалістів, компетентних в галузі кардіореабілітаці та превентивної кардіології, необхідно створити навчальні програми, які базуються на рекомендаціях української та міжнародних спільнот фахівців. Використовувати можливість дистанційного навчання за програмою Європейської асоціації превентивної кардіології, яка доступна на офіційному сайті Європейської асоціації кардіологів, практичних курсів з КР та рекомендацій щодо реабілітації хворих з ССЗ, розроблених Європейським товариством фізичної та реабілітаційної медицини, Європейською асоціацією превентивної кардіології, Американською асоціацією серця $[16,17,20]$.

4. Враховуючи наявність в Україні розвиненої інфраструктури СКЗ та механізму фінансування реабілітаційних послуг, які вони надають, доцільно організувати на їх базі продовження стаціонарного етапу, а також надати можливість проведен- 
Огляди літератури, оригінальні дослідження, погляд на проблему, ювілеї

ня амбулаторної реабілітації місцевих жителів. У зв'язку з цим необхідно спростити процедури направлення до СK3, що забезпечить ранній початок реабілітації та її ефективність. Облаштувати маршрути дозованої ходьби на території медичних закладів і в населених пунктах, що дозволить знизити витрати на технічне забезпечення ПКР (велоергометри, тредміли), швидше відновити фізичну працездатність та підвищити прихильність до підтримки достатнього рівня фізичної активності у віддаленому періоді. Розвинені країни $\epsilon_{\mathrm{B}-}$ ропи, зокрема Великобританія, мають позитивний досвід створення в містах простору, який сприяє фізичній активності та соціальній інтеграції людей похилого віку. Подібна практика може бути використана в Україні задля організації реабілітації на рівні громади.

Модель КР в Україні має адаптуватись до індивідуальних потреб пацієнта, рівня технічного забезпечення медичного закладу та кадрових ресурсів. Запропоновану модель подано в таблиці 2.

Таблиця 2. Модель організації кардіореабілітації в Україні

\begin{tabular}{|l|l|l|}
\hline I Фаза & Гострий період & $\begin{array}{l}\text { Відділення інтенсивної терапії, реперфузійний центр, кардіохірургічне } \\
\text { відділення }\end{array}$ \\
\cline { 2 - 3 } & Підгострий період & $\begin{array}{l}\text { Кардіологічне відділення або СК3, які мають фахівців, компетентних в галузі } \\
\text { КР, необхідне технічне оснащення, та входять до переліку СК3 ФССУ за } \\
\text { Спеціалізацією «Кардіопульмонарна реабілітація» }\end{array}$ \\
\hline $\begin{array}{l}\text { II Фаза } \\
\text { Амбулаторна }\end{array}$ & $\begin{array}{l}\text { Центри первинної медико-соціальної допомоги або СК3 за напрямком } \\
\text { «Кардіопульмонарна реабілітація», уразі недоступності ПКРвикористовувати } \\
\text { Можливості телереабілітації }\end{array}$ \\
\hline $\begin{array}{l}\text { III Фаза } \\
\text { Домашні/на базі громади }\end{array}$ & $\begin{array}{l}\text { Виконання рекомендацій, наданих на попередніх етапах, періодичний } \\
\text { Медичний контроль, використання можливостей телереабілітації }\end{array}$ \\
\hline
\end{tabular}

3 метою зменшення витрат на КР доцільно:

1. Розробити вітчизняні мобільні додатки, створити електронні інформаційні ресурси, на базі яких буде проводитись телереабілітація.

2. Активно використовувати технічні засоби моніторування основних показників роботи серцево-судинної системи і факторів ризику (годинники та інші гаджети з можливістю запису ЕКГ, крокоміри з додатковими функціями, мобільні додатки), що допоможе забезпечити дистанційний контроль і підтримку прихильності пацієнтів до ПКР.

3. Систематично проводити санітарно-просвітницьку роботу серед населення стосовно факторів ризику ССЗ та можливостей їх контролю.

4. Започаткувати школи пацієнтів при центрах первинної медико-санітарної допомоги, із залученням до їх проведення середнього медичного персоналу та студентів закладів медичної освіти.

5. Використовувати досвід інших держав. Наприклад, в країнах з розвиненою КР існує практика мотивації лікарів первинної ланки надавати реабілітаційні послуги на амбулаторному етапі пацієнтам з ССЗ. Зокрема, в Швейцарії сімейні лікарі отримують доплати за створення рецепту фізичних вправ для домашніх ПКР. Введення амбула- торних ПКР як госпрозрахункових послуг в центрах первинної медико-санітарної допомоги сприятиме мотивації керівників закладів охорони здоров'я та лікарів первинної ланки надання медичної допомоги.

Завданнями, які необхідно вирішити, щоб зробити КР доступною для більшості населення України, $\epsilon$ :

- проведення досліджень з оцінки економічної ефективності компонентів КР в Україні;

- розробка мінімальних стандартів ПКР для закладів та фахівців, які мають право надавати реабілітаційні послуги кардіологічним хворим на різних етапах;

- створення навчальних програм та підготовка фахівців, компетентних в реабілітації хворих із CC3;

- удосконалення існуючих та створення нових механізмів фінансування ПКР;

- проведення заходів з подолання бар'єрів участі в ПКР;

- розробка оптимального маршруту пацієнта після гострих серцево-судинних подій та оперативних втручань на серці в різних областях України;

- створення національного реєстру пацієнтів, які беруть участь в ПКР. 
Огляди літератури, оригінальні дослідження, погляд на проблему, ювілеї ЛІТЕРАТУРА

1. Коваленко В. М. Серцево-судинні хвороби: медично-соціальне значення та стратегія розвитку кардіології в Україні / В. М. Коваленко, А. П. Дорогой, - 2016.

2. Al Quait A. I. M. Overview of cardiac rehabilitation evidence, benefits and utilization / A. I. M. Al Quait, P. J. Doherty // Global Journal of Health Science. - 2017. - P. 38-48.

3. Wenger N. Cardiac rehabilitation / N. Wenger // Cardiovasc. Prev. and Rehab. - 2007. Vol. 34. - P. 1-11.

4. Lavie C. J. Adverse psychological and coronary risk profiles in young patients with coronary artery disease and benefits of formal cardiac rehabilitation / C. J. Lavie, R. V. Milani // Archives of Internal Medicine. - 2006. Vol. 166, No.17. - P. 1878-1883.

5. Meta-analysis: secondary prevention programs for patients with coronary artery disease / A. M. Clark, L. Hartling, B. Vandermeer, F. A. McAlister // Annals of Internal Medicine. - 2005. - Vol. 143, No. 9. - P. 659-672.

6. Willmer K. A. Clinical papers-Long-term benefits of cardiac rehabilitation: A five-year follow-up of communitybased phase 4 programmes / K. A. Willmer, M. Waite // British Journal of Cardiology. - 2009. - Vol. 16, No. 2. - P. 73.

7. Cost-effectiveness of cardiac rehabilitation: a systematic review / G. E. Shields, A. Wells, P. Doherty [et al.] // Heart. -2018.

8. Exercise-based rehabilitation for patients with coronary heart disease: systematic review and meta-analysis of randomized controlled trials / A. Brown, S. Ebrahim, R. S. Taylor [et al.] // The American Journal of Medicine. - 2004. Vol. 116, No. 10. - P. 682-692.

9. A review of cardiac rehabilitation delivery around the world / E. Pesah, M. Supervia, K. Turk-Adawi, S. L. Grace // Progress in Cardiovascular Diseases. - 2017.

10. Piepoli M. F. Challenges in secondary prevention after acute myocardial infarction: A call for action / M. F. Piepoli // European Journal of Preventive Cardiology. 2016. - Vol. 23, No. 18. - P. 1994-2006.

11. Lear S. A. Cardiac rehabilitation: a comprehensive review / S. A. Lear, A. Ignaszewski // Trials. - 2001. - Vol. 2, No. 5. - P. 221.

12. Clinical evidence for a health benefit from cardiac rehabilitation: an update / M. A. Williams, P. A. Ades, L. F. Hamm [et al.] // American Heart Journal. - 2006. Vol. 152, No. 5. - P. 835-841.

13. Bittner V. Core components of cardiac rehabilitation/secondary prevention programs: 2007 Update / V. Bittner, J. A. M. Foody // Journal of Cardiopulmonary Rehabilitation and Prevention. - 2007. - Vol. 27, No. 121/129.

14. Australian Cardiovascular Health and Rehabilitation Association (ACRA) core components of cardiovascular disease secondary prevention and cardiac rehabilitation 2014 / S. Woodruffe, L. Neubeck, R. A. Clark [et al.] // Heart, Lung and Circulation. - 2015. - Vol. 24, No. 5. P. 430-441.

15. Cardiac rehabilitation and risk reduction: time to "rebrand and reinvigorate" / P. B. Sandesara, C. T. Lambert, N. F. Gordon [et al.] // Journal of the American College of Cardiology. - 2015. - Vol. 65, No. 4. - P. 389-395.

16. Evidence-based position paper on Physical and Rehabilitation Medicine (PRM) professional practice for people with cardiovascular conditions. The European PRM position (UEMS PRM Section) / A. Juocevicius, A. Oral,

A. Lukmann [et al.] // European Journal of Physical and Rehabilitation Medicine.-2018.-Vol.54, No. 4.-P.634-643.

17. Secondary prevention in the clinical management of patients with cardiovascular diseases. Core components, standards and outcome measures for referral and delivery: a policy statement from the cardiac rehabilitation section of the European Association for Cardiovascular Prevention \& Rehabilitation. Endorsed by the Committee for Practice Guidelines of the European Society of Cardiology / M. F. Piepoli, U. Corra, S. Adamopoulos [et al.] // European Journal of Preventive Cardiology. - 2014. - Vol. 21, No. 6. P. 664-681.

18. Cardiac rehabilitation delivery model for lowresource settings: an international council of cardiovascular prevention and rehabilitation consensus statement // S. L. Grace, K. I. Turk-Adawi, A. Contractor [et al.] // Progress in Cardiovascular Diseases. - 2016. - Vol. 59, No. 3. P. 303-322.

19. Centers for Medicare \& Medicaid Services. Decision memo for cardiac rehabilitation (CR) programs chronic heart failure (CAG-00437N) // Medicare Coverage Database. Baltimore, MD: CMS. - 2014.

20. Balady G. J. American Heart Association Exercise, Cardiac Rehabilitation, and Prevention Committee, the Council on Clinical Cardiology; American Heart Association Council on Cardiovascular Nursing; American Heart Association Council on Epidemiology and Prevention; American Heart Association Council on Nutrition, Physical Activity, and Metabolism; American Association of Cardiovascular and Pulmonary Rehabilitation. Core components of cardiac rehabilitation/secondary prevention programs: 2007 update: a scientific ... // Circulation. - 2007. - Vol. 115. - P. 2675-2682.

21. ESC. Prevention of CVD Programme: Rehabilitation [Electronic resource] / ESC. - 2018. - Mode access: https:// www.escardio.org/Education/ESC-Prevention-of-CVDProgramme/Rehabilitation.

22. Increasing cardiac rehabilitation participation from 20\% to $70 \%$ : a road map from the Million Hearts Cardiac Rehabilitation Collaborative / P. A. Ades, S. J. Keteyian, J. S. Wright [et al.] // Mayo Clinic Proceedings. - Elsevier, 2017. - Vol. 92, No. 2. - P. 234-242.

23. Малиновская И. Э., Шумаков В. А., Терещенко Н. М. Ранняя постгоспитальная кардиореабилитация пациентов после инфаркта миокарда - основа эффективной вторичной профилактики. - 2016.

24. Kaiser M. Making the case for cardiac rehabilitation: modelling potential impact on readmissions / M. Kaiser, M. Varvel, P. Doherty // NHS Improvement, London. - 2013.

25. De Gruyter E. Economic and social impact of increasing uptake of cardiac rehabilitation services-a cost benefit analysis / E. De Gruyter, G. Ford, B. Stavreski // Heart, Lung and Circulation. - 2016. - Vol. 25, No. 2. - P. 175-183.

26. Noncommunicable diseases in Africa: a silent hypertension epidemic in Eritrea / J. Mufunda, P. Nyarango, A. Kosia [et al.] // Journal of Human Hypertension. - 2005. Vol. 19, No. 3. - P. 255

27. World Health Organization. Part three - what works: the evidence for action // Preventing chronic diseases: a vital investment. WHO Global Report. - 2005.

28. Advocacy for outpatient cardiac rehabilitation globally // A. S. Babu, F. Lopez-Jimenez, R. J. Thomas [et 
Огляди літератури, оригінальні дослідження, погляд на проблему, ювілеї

al.] // BMC Health Services Research. - 2016. - Vol. 16, No. 1. - P. 471.

29. Фонд соціального страхування України [Електронний ресурс]. - 2018. - Режим доступу до ресурсу: http://www.fse.gov.ua/fse/control/main/uk/publish/ article/954736.

30. Фонд соціального страхування України [Електронний ресурс]. - 2018. - Режим доступу до ресурсу: http:// www.fssu.gov.ua/fse/control/kievobl/uk/publish/article/927 93;jsessionid=430E4043EAC9CC889FCB73708E712C38.

31. Фонд соціального страхування України [Електронний ресурс]. - 2018. - Режим доступу до ресурсу: http://www.fssu.gov.ua/fse/control/main/uk/publish/ article/952253.

32. Кабінет Міністрів України. Уряд повністю забезпечує фінансування санаторно-курортного лікування для пільгових категорій громадян. [Електронний ресурс]. - 2018. - Режим доступу до ресурсу: https: //www. mu.gov.ua/ua/news/uryad-povnistyu-zabezpechuyefinansuvannya-sanatorno-kurortnogo-likuvannya-dlyapilgovih-kategorij-gromadyan.

33. Кардіоцентри. [Електронний ресурс]. - 2018. Режим доступу до ресурсу: http://moz.gov.ua/ kardiocentri.

\section{REFERENCES}

1. Kovalenko, V.M., \& Dorohoi, A.P. (2016). Sertsevosudynni khvoroby: medychno-sotsialne znachennia ta stratehiia rozvytku kardiolohii v Ukraini [Cardiovascular diseases: medical and social significance and strategy of cardiology development in Ukraine]. [in Ukrainian].

2. Al Quait, A.I.M., \& Doherty, P.J. (2017). Overview of Cardiac Rehabilitation Evidence, Benefits and Utilisation. Global Journal of Health Science, 38-48.

3. Wenger, N. (2007). Cardiac rehabilitation. Cardiovasc. Prev. and Rehab., 34, 1-11.

4. Lavie, C.J., \& Milani, R.V. (2006). Adverse psychological and coronary risk profiles in young patients with coronary artery disease and benefits of formal cardiac rehabilitation. Archives of Internal Medicine, 166 (17), 1878-1883.

5. Clark, A.M., Hartling, L., Vandermeer, B., \& McAlister, F.A. (2005). Meta-analysis: secondary prevention programs for patients with coronary artery disease. Annals of Internal Medicine, 143 (9), 659-672.

6. Willmer, K.A., \& Waite, M. (2009). Clinical papersLong-term benefits of cardiac rehabilitation: A five-year follow-up of community-based phase 4 programmes. British Journal of Cardiology, 16 (2), 73.

7. Shields, G.E., Wells, A., Doherty, P., Heagerty, A., Buck, D., \& Davies, L. M. (2018). Cost-effectiveness of cardiac rehabilitation: a systematic review. Heart.

8. Taylor, R.S., Brown, A., Ebrahim, S., Jolliffe, J., Noorani, H., Rees, K., \& Oldridge, N. (2004). Exercise-based rehabilitation for patients with coronary heart disease: systematic review and meta-analysis of randomized controlled trials. The American Journal of Medicine, 116 (10), 682-692.

9. Pesah, E., Supervia, M., Turk-Adawi, K., \& Grace, S.L. (2017). A review of cardiac rehabilitation delivery around the world. Progress in Cardiovascular Diseases.

10. Piepoli, M.F., Corrà, U., Dendale, P., Frederix, I., Prescott, E., Schmid, J. P., ... \& Graham, I. (2016). Challenges in secondary prevention after acute myocardial infarction: A call for action. European Journal of Preventive Cardiology, 23 (18), 1994-2006.

11. Lear, S.A., \& Ignaszewski, A. (2001). Cardiac rehabilitation: a comprehensive review. Trials, 2 (5), 221.

12. Williams, M.A., Ades, P.A., Hamm, L.F., Keteyian, S.J., LaFontaine, T.P., Roitman, J.L., \& Squires, R.W. (2006). Clinical evidence for a health benefit from cardiac rehabilitation: an update. American Heart Journal, 152 (5), 835841.
13. Bittner, V., \& Foody, J.A.M. (2007). Core components of cardiac rehabilitation/secondary prevention programs: 2007 Update. Journal of Cardiopulmonary Rehabilitation and Prevention, $27(121 / 129)$.

14. Woodruffe, S., Neubeck, L., Clark, R. A., Gray, K., Ferry, C., Finan, J., ... \& Briffa, T. G. (2015). Australian Cardiovascular Health and Rehabilitation Association (ACRA) core components of cardiovascular disease secondary prevention and cardiac rehabilitation 2014. Heart, Lung and Circulation, 24 (5), 430-441.

15. Sandesara, P.B., Lambert, C.T., Gordon, N.F., Fletcher, G.F., Franklin, B. A., Wenger, N.K., \& Sperling, L. (2015). Cardiac rehabilitation and risk reduction: time to "rebrand and reinvigorate". Journal of the American College of Cardiology, 65 (4), 389-395.

16. Juocevicius, A., Oral, A., Lukmann, A., Takáč, P., Tederko, P., Hāznere, I., ... \& Christodoulou, N. (2018). Evidence-based position paper on Physical and Rehabilitation Medicine (PRM) professional practice for people with cardiovascular conditions. The European PRM position (UEMS PRM Section). European Journal of Physical and Rehabilitation Medicine, 54 (4), 634-643.

17. Piepoli, M.F., Corra, U., Adamopoulos, S., Benzer, W., Bjarnason-Wehrens, B., Cupples, M., ... \& McGee, H. (2014). Secondary prevention in the clinical management of patients with cardiovascular diseases. Core components, standards and outcome measures for referral and delivery: a policy statement from the cardiac rehabilitation section of the European Association for Cardiovascular Prevention \& Rehabilitation. Endorsed by the Committee for Practice Guidelines of the European Society of Cardiology. European Journal of Preventive Cardiology, 21 (6), 664-681.

18. Grace, S.L., Turk-Adawi, K.I., Contractor, A., Atrey, A., Campbell, N.R., Derman, W., ... \& Buckley, J. (2016). Cardiac rehabilitation delivery model for low-resource settings: an international council of cardiovascular prevention and rehabilitation consensus statement. Progress in Cardiovascular Diseases, 59 (3), 303-322.

19. Centers for Medicare \& Medicaid Services. (2014). Decision memo for cardiac rehabilitation (CR) programschronic heart failure (CAG-00437N). Medicare Coverage Database. Baltimore, MD: CMS.

20. Balady, G.J. (2007). American Heart Association Exercise, Cardiac Rehabilitation, and Prevention Committee, the Council on Clinical Cardiology; American Heart Association Council on Cardiovascular Nursing; American 
Огляди літератури, оригінальні дослідження, погляд на проблему, ювілеї

Heart Association Council on Epidemiology and Prevention; American Heart Association Council on Nutrition, Physical Activity, and Metabolism; American Association of Cardiovascular and Pulmonary Rehabilitation. Core components of cardiac rehabilitation/secondary prevention programs: 2007 update: a scientific .... Circulation, 115, 26752682.

21. ESC Prevention of CVD Programme: Rehabilitation. (2018). Retrieved from https://www.escardio.org/ Education/ESC-Prevention-of-CVD-Programme/Rehabilitation.

22. Ades, P.A., Keteyian, S.J., Wright, J.S., Hamm, L.F., Lui, K., Newlin, K., ... \& Thomas, R.J. (2017). Increasing cardiac rehabilitation participation from $20 \%$ to $70 \%$ a road map from the Million Hearts Cardiac Rehabilitation Collaborative. In Mayo Clinic Proceedings, 92 (2), 234-242. Elsevier.

23. Malinovskaya, I.E., Shumakov, V.A., \& Tereshchenko, N.M. (2016). Rannyaya postgospitalnaya kardioreabilitatsiya patsiyentov posle infarkta miokarda - osnova effektivnoy vtorichnoy profilaktiki [Early post-hospital cardiorehabilitation of patients after myocardial infarction is the basis of effective secondary prevention]. [in Russian].

24. Kaiser, M., Varvel, M., \& Doherty, P. (2013). Making the case for cardiac rehabilitation: modelling potential impact on readmissions. NHS Improvement, London.

25. De Gruyter, E., Ford, G., \& Stavreski, B. (2016). Economic and social impact of increasing uptake of cardiac rehabilitation services-a cost benefit analysis. Heart, Lung and Circulation, 25 (2), 175-183.

26. Mufunda, J., Nyarango, P., Kosia, A., Obgamariam, A., Mebrahtu, G., Usman, A., ... \& Tesfay, A. (2005). Noncommu-

nicable diseases in Africa: a silent hypertension epidemic in Eritrea. Journal of Human Hypertension, 19 (3), 255.

27. World Health Organization. (2005). Part three what works: the evidence for action. Preventing chronic diseases: a vital investment. WHO Global Report.

28. Babu, A. S., Lopez-Jimenez, F., Thomas, R. J., Isaranuwatchai, W., Herdy, A.H., Hoch, J.S., \& Grace, S.L. (2016). Advocacy for outpatient cardiac rehabilitation globally. BMC Health Services Research, 16 (1), 471.

29. (2018). Fond sotsialnoho strakhuvannia Ukrainy [Social Insurance Fund of Ukraine]. Retrieved from: http://www. fse.gov.ua/fse/control/main/uk/publish/article/954736.

30. (2018). Fond sotsialnoho strakhuvannia Ukrainy [Social Insurance Fund of Ukraine]. Retrieved from: http:// www.fssu.gov.ua/fse/control/kievobl/uk/publish/articl e/92793;jsessionid=430E4043EAC9CC889FCB73708E71 $2 \mathrm{C} 38$.

31. (2018). Fond sotsialnoho strakhuvannia Ukrainy [Social Insurance Fund of Ukraine]. Retrieved from: http:// www.fssu.gov.ua/fse/control/main/uk/publish/article/952253.

32. (2018). Kabinet Ministriv Ukrainy - Uriad povnistiu zabezpechuie finansuvannia sanatorno-kurortnoho likuvannia dlia pilhovykh katehorii hromadian [The Cabinet of Ministers of Ukraine. The government fully provides funding for sanatorium treatment for privileged citizens]. Retrieved from: https://www.kmu.gov.ua/ua/news/uryadpovnistyu-zabezpechuye-finansuvannya-sanatorno-kurortnogo-likuvannya-dlya-pilgovih-kategorij-gromadyan.

33. (2018). Kardiotsentry [Cardiocenters]. Retrieved from: http://moz.gov.ua/kardiocentri.

\title{
ЭКОНОМИЧЕСКАЯ ЭФФЕКТИВНОСТЬ И ОРГАНИЗАЦИОННЫЕ АСПЕКТЫ РЕАЛИЗАЦИИ ПРОГРАММ КАРДИОРЕАБИЛИТАЦИИ СОГЛАСНО МЕЖДУНАРОДНОМУ ОПЫТУ, ПЕРСПЕКТИВЫ РАЗВИТИЯ В УКРАИНЕ
}

\author{
ФП. Ф. Колесник, О. В. Долынная, С. П. Колесник, И. В. Баранова
}

\author{
Винницкий национальный медицинский университет имени Н. И. Пирогова
}

РЕЗЮМЕ. Сердечно-сосудистые заболевания (ССЗ) продолжают занимать первое место среди причин смертности трудоспособного населения, а их распространенность выше в странах с низким и средним уровнями дохода. В связи с ограниченными финансовыми ресурсами этих стран, возникает необходимость рационального распределения средств, выделенных на здравоохранение. Особенное значение в этих условиях приобретают превентивная кардиология и кардиореабилитация (КР).

Цель-провести обзор научной литературы, посвященнойэкономическойэффективностии организационным аспектам реализации программ КР в странах с разным уровнем доходов; предложить модель для Украины.

Материал и методы. Проведен обзор литературы по избранной теме в наукометрической базе данных MEDLINE и на официальных электронных ресурсах международных объединений кардиологов, врачей физической и реабилитационной медицины. Поиск проведен по ключевым словам: cardiac rehabilitation, cardiorehabilitation, cardiovascular rehabilitation, low/middle income country, core components, models, benefit, effectiveness, economic effectiveness.

Результаты и выводы. В статье проанализирована эффективность и описаны особенности организации КР в странах с разным уровнем доходов. На основании обзора литературы сделаны выводы о возможных путях развития и предложена модель организации КР в Украине. Использование альтернативных моделей КР может повысить её доступность для большинства населения Украины, улучшить качество жизни и снизить смертность от СС3.

КЛЮЧЕВЫЕ СЛОВА: кардиореабилитация; эффективность; модели; страны с низким и средним уровнями дохода. 


\title{
ECONOMIC EFFICIENCY AND ORGANIZATIONAL ASPECTS OF IMPLEMENTATION OF CARDIAC REHABILITATION PROGRAMS ACCORDING TO INTERNATIONAL EXPERIENCE, PROSPECTS OF DEVELOPMENT IN UKRAINE
}

\author{
@P. F. Kolisnyk, O. V. Dolynna, S. P. Kolisnyk, I. V. Baranova
}

M. Pyrohov Vinnytsia National Medical University

Department of Medical Rehabilitation and Medical Social Expertise

SUMMARY. Cardiovascular diseases (CVD) continue to occupy the first place among the causes of mortality of the working-age population, and their prevalence is higher in low- and middle-income countries. Due to the limited financial resources of these countries, there is a need for rational allocation of funds allocated for health care. Preventive cardiology and cardiac rehabilitation (CR) acquire of particular importance in these conditions.

The aim - to review the scientific literature on the economic efficiency and organizational aspects of the implementation of the CR programs in countries with different income levels, to propose a model for Ukraine.

Material and Methods. The review of the literature on a selected topic in the MEDLINE database and on official electronic resources of international associations of cardiologists, physicians of physical and rehabilitation medicine was conducted. The search was conducted by keywords: cardiac rehabilitation, cardiorehabilitation, cardiovascular rehabilitation, low/middle income country, core components, models, benefit, effectiveness, economic effectiveness.

Results and Conclusion. The article analyzes the effectiveness and describes the features of the organization of the CR in countries with different income levels. Based on the review of the literature, conclusions were drawn on possible ways of development and a model of the organization of the CR in Ukraine was proposed. The use of alternative CR models can increase its accessibility for the majority of the population of Ukraine, improve the quality of life and reduce the mortality from CVD.

KEY WORDS: cardiac rehabilitation; cardiovascular rehabilitation; effectiveness; models; low/middle-income countries.

Отримано 01.11.2018 